\title{
Адаптація дітей середнього шкільного віку до умов дистанційного навчання у процесі фізичного виховання
}

\author{
УДК [374.1:372.879.6]+572.025 \\ О. В. Маслова, Є. В. Імас, Л. Г. Шахліна, \\ С. М. Футорний, Т. В. Коломієць, А. О. Утвенко
}

Національний університет фізичного виховання і спорту України, Київ, Україна

\begin{abstract}
Резюме. Дистанційна освіта в сучасних реаліях набуває неабиякого значення і досить активно намагається створити міцний симбіоз із класичною освітою, у тому числі й у системі фізичного виховання, що вимагає модернізації контролю у бік його посилення за ефективністю даного процесу, пов'язаного з гіперактивацією та ризиком перенапруження адаптаційних можливостей організму школярів під час ознайомлення, вивчення і засвоєння навчального матеріалу з предмета «Фізична культура» за допомогою новітніх засобів і методів дистанційної форми навчання. Мета. Визначити основні напрями проблематики дослідження адаптації школярів до умов дистанційного навчання у процесі фізичного виховання. Методи. Аналіз і узагальнення даних спеціальної науково-методичної літератури; моніторинг інформаційних ресурсів мережі Інтернет; систематизація; контент-аналіз. Результати. Отримані дані визначили стратегію формулювання проблематики питання дослідження шкільної адаптації, змісту і структури даного поняття та його імплементацію через системний аналіз до конкретизації основних напрямів дослідження; забезпечили вивчення сучасних поглядів, специфіки та рекомендаційних основ впровадження дистанційної форми навчання у систему середньої освіти України і, зокрема, у процес фізичного виховання школярів окремих вікових груп; виокремили аспекти дослідження навчальної та методичної документації, нормативно-правових документів щодо запровадження дистанційної форми навчання в Україні та об'єднали їх з основними напрямами дослідження проблематики шкільної адаптації. Відсутня систематизація рішень та узгодження концепції загальних дій, розроблення технології (алгоритму) наповнення взаємозалежних пунктів мети, завдань, принципів, методів, засобів й оцінювання ефективності процесу адаптації школярів до умов дистанційної освіти в межах процесу їх фізичного виховання, на що у майбутньому і буде безпосередньо спрямовано подальші дослідження.
\end{abstract}

Ключові слова: адаптація, дистанційна освіта, дистанційна форма навчання, фізичне виховання, школярі, здоров'я.

\section{Adaptation of middle school age children to the distance learning conditions in the process of physical education}

O. V. Maslova, Ye. V. Imas, L. G. Shakhlina, S. M. Futornyi, T. V. Kolomiyets, A. O. Utvenko National University of Physical Education and Sport of Ukraine, Kyiv, Ukraine

Abstract. Distance education in modern realities have great importance and is actively trying to create a strong symbiosis with classical education, including in the system of physical education, which requires modernization of control to strengthen it by the effectiveness of this process associated with hyperactivation and the risk of overexertion of the adaptation process of pupils during the acquaintance, study and assimilation of educational material in the subject of «Physical Culture» using the latest tools and methods of distance learning. Objective. To determine the main directions of studying the pupils' adaptation to the conditions of distance learning in the process of physical education. Methods. Analysis and generalization of special scientific and methodical literature; monitoring the Internet information resources; systematization method; content-analysis. 
Results. The findings determined the strategy of formulating the issue of research «school adaptation", determining the content and structure of this concept and its implementation through systematic analysis to specify the main areas of research; provided the study of modern views, specifics and recommendation bases of distance learning introduction at the system of secondary education of Ukraine, and in particular in the process of physical education of schoolchildren of certain age groups; singled out aspects of the study of educational and methodological documentation, legal documents on the introduction of distance learning in Ukraine and combined them with the main areas of research on «school adaptation». There is no systematization of decisions and coordination of the concept of general actions, development of technology (algorithm) of filling of interdependent points of the purpose, tasks, principles, methods, means and an estimation of efficiency of process of adaptation of schoolboys to conditions of distance education within their process of physical education, further research is directed.

Keywords: adaptation, distance education, distance learning, physical education, schoolchildren, health.

Постановка проблеми. Загальна глобалізація та модернізація української освіти, обумовлена сучасними тенденціями інформатизації світового суспільства, активно інтегрує, поряд 3 традиційною, класичною формою навчання, високотехнологічний продукт науково-технічного прогресу - дистанційну організацію навчального процесу - на всіх рівнях освіти [3, 15].

Дистанційна освіта - освітній процес, у якому значна частина викладання здійснюється вчителем (чи групою вчителів), віддаленим у просторі або часі від учня (чи групи учнів), а головною метою виступає забезпечення доступу до освітніх ресурсів через використання сучасних інформаційних технологій і мереж $[4,8]$.

В Україні процес запровадження та інтеграції дистанційної форми навчання у систему освіти регулюється Концепцією розвитку дистанційної освіти України і Положенням про дистанційне навчання від 25.04.2013 [4].

Введення карантину у зв'язку з пандемією COVID-19 у світі й Україні привело до стимуляції процесу трансфрормації освітнього простору, заміни звичних фрорм і методів викладання навчальних дисциплін, у тому числі і фрізичного виховання, та активного переходу на дистанційну форому навчання $[9,16]$.

Надбання та засвоєння школярами теоретичних знань і практичних навичок у галузі фрізичного виховання, формування і збереження здоров'я $\epsilon$ метою дистанційної фооми викладання навчального предмета «Фізична культура», що потребує розроблення та впровадження новітніх засобів самоорганізації рухової діяльності учнів, оцінювання та контролю ефективності їх інтеграції у навчальний процес школярів різних вікових груп $[12,14]$.

Проте прогресування дистанційної форми освіти в Україні та інтенсифікація процесу освоєння новітніх інорормаційних технологій збільшили як фрізичне, так і психоемоційне навантаження на всіх його учасників, перш за все школярів, адже мінімальний за силою, але тривалий вплив надмірних, неадекватних до індивідуальних особливостей організму дитини чинників може перевищити адаптаційні можливості та призвести до потенціювання процесів дезадаптації, що в свою чергу викликає порушення соматичного, психічного, фрізичного здоров'я [5, 10, 11].

Такий факт обумовлює актуальність наших досліджень у напрямі обгрунтування необхідності розроблення, апробації та впровадження системи постійного моніторингу адаптаційно-резервних можливостей організму дітей різних віково-статевих груп у сучасних умовах регламентування навчального навантаження дистанційною формою навчання.

Мета дослідження - визначити основні напрями проблематики дослідження адаптації школярів до умов дистанційного навчання у процесі фрізичного виховання.

Методи дослідження: аналіз і узагальнення даних спеціальної науково-методичної літератури; моніторинг інформаційних ресурсів мережі Інтернет; систематизація; контент-аналіз.

Аналіз і узагальнення даних спеціальної науково-методичної літератури першочергово передбачали формулювання проблематики питання дослідження шкільної адаптації, визначення змісту і структури цього поняття та його імплементацію через системний аналіз до конкретизації основних напрямів дослідження.

Моніторинг інфоормаційних ресурсів мережі Інтернет забезпечив вивчення сучасних поглядів, специфріки та рекомендаційних основ впровадження дистанційної форми навчання у систему середньої освіти України i, зокрема, у процес фрізичного виховання школярів окремих вікових груп.

Метод систематизації дозволив виокремити аспекти дослідження навчальної та методичної документації, нормативно-правових документів 


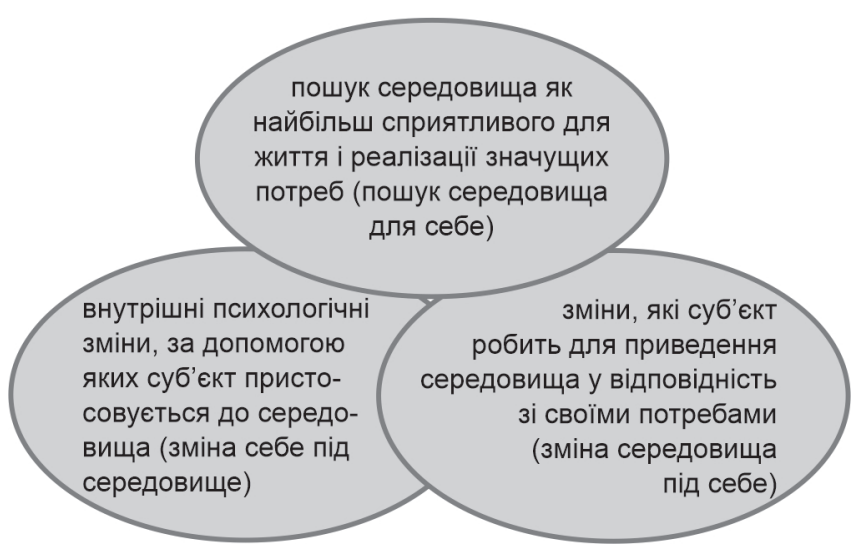

Рисунок 1 - Основні форми адаптації до зовнішнього середовища

щодо запровадження дистанційної форми навчання в Україні, а контент-аналіз поєднав їх 3 основними напрямами дослідження проблематики шкільної адаптації, визначеними у ході аналізу й узагальнення даних спеціальної науково-методичної літератури.

Результати дослідження та їх обговорення. Аналіз і узагальнення даних спеціальної науково-методичної літератури продемонстрував, що підвищена чутливість організму школярів до фракторів зовнішнього середовища збільшує ризик виникнення порушень розвитку та стану здоров'я дитини. Реалізація несприятливих фракторів при фрормуванні патології значною мірою залежить від сили і тривалості їх дії, віку дитини та її спадковості, співвідношень негативних і позитивних впливів. Адаптація розглядається більшістю авторів як процес активного пристосування індивіда до умов середовища і як результат цього процесу (рис. 1) [10, 13].

Шкільна адаптація - процес пристосування організму школярів до нових умов життєдіяльності, нового виду діяльності, нових наванта- жень, пов'язаних зі систематичним навчанням. Цей процес тривалий і має фрізіологічні, психологічні та соціальні аспекти (рис. 2) [10, 13].

Результатом адаптації $\epsilon$ здатність організму фуннціонувати в нових для нього умовах при збереженні параметрів гомеостазу і високої працездатності [10, 13].

При довготривалому процесі адаптації організм перебуває в стресовому стані, відбувається напруження регуляторних механізмів та можливе виникнення «зриву адаптації» [10, 11, 13].

Відомо, що рівень резервних можливостей дорослої людини майже в два рази вище, ніж дитини молодшого шкільного віку [10, 11, 13].

Організм дитини, як і дорослої людини, використовує свої резервні можливості для збереження параметрів гомеостазу під дією фракторів середовища, але якщо дія певного фактора перевищує можливості організму (за тривалістю дії та/або силою), то наслідком таких перенавантажень може стати погіршення здоров'я дитини $[10,11,13]$.

Проявом дезапдаптації можуть бути різні порушення здоров'я залежно від того, на якому рівні нейроендокринної регуляції відбувається виснаження. Найбільш характерними проявами дезадаптації $€$ вегето-судинні дистонії, хронічна перевтома, нервово-психічні розлади, зниження резистентності організму. Найчастіше «хворобами адаптації» можуть бути виразкова хвороба шлунка та дванадцятипалої кишки, алергічні, ендокринні, серцево-судинні хвороби, патології опорно-рухового апарату, сенсорної та дихальної систем [10, 11, 13].

Проблема адаптації дитини до освітнього шкільного простору нерозривно пов'язана 3 проблемою виникнення шкільної дезадаптації складного соціально-психологічного і соціальнопедагогічного явища, що перешкоджає успішно-
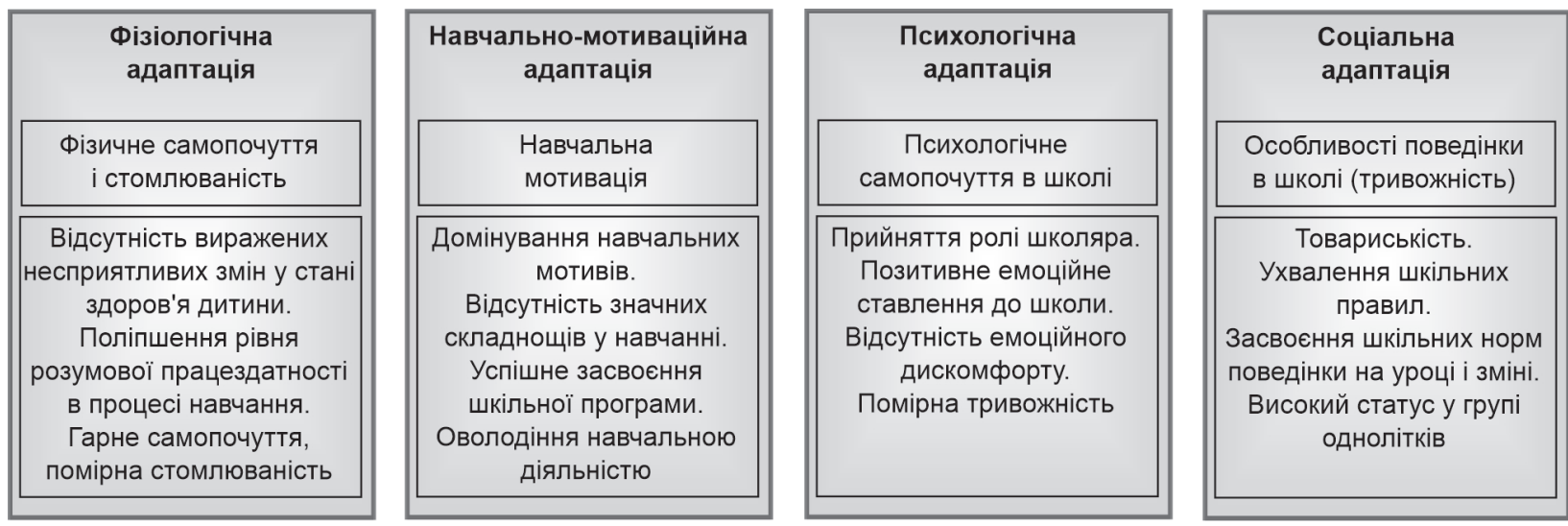

Рисунок 2 - Структура адаптації дітей до навчання у школі $[10,13]$ 


\begin{tabular}{|c|c|c|}
\hline $\begin{array}{c}\text { Психофрізіологічні } \\
\text { ознаки: }\end{array}$ & $\begin{array}{c}\text { Психологічні } \\
\text { ознаки: }\end{array}$ & $\begin{array}{c}\text { Соціально- } \\
\text { середовищні } \\
\text { ознаки: }\end{array}$ \\
\hline \begin{tabular}{|l} 
- відхилення \\
психофізичного \\
розвитку; \\
- соматичне \\
ослаблення; \\
- церебрально- \\
органічна \\
недостатність
\end{tabular} & $\begin{array}{l}\text { • порушення } \\
\text { поведінки; } \\
\text { - зниження } \\
\text { навчальної } \\
\text { мотивації }\end{array}$ & \begin{tabular}{|l|} 
- характер \\
сімейних \\
відносин; \\
- особливості \\
шкільного \\
освітнього \\
середовища; \\
- характер \\
міжособистісних \\
відносин
\end{tabular} \\
\hline
\end{tabular}

Рисунок 3 - Структура дезадаптації дітей до навчання у школі $[2,13]$

му оволодінню школярем у процесі навчальної діяльності знаннями, вміннями, навичками спілкування і взаємодії (рис. 3) $[10,11,13]$.

Серед причин порушення (зриву) адаптації науковці називають неадекватність вимог педагога, батьків; стрес від обмеження часу; негативне підкріплення, суперечливість вимог, завищені вимоги; перенавантаження (емоційні, інтелектуальні та фрізичні); невідповідність програм, методик, технологій віковим та індивідуальним можливостям; порушення режиму й організації навчальних і позанавчальних занять; порушення психічного і фрізичного здоров'я; психологічна та функціональна неготовність до умов і вимог процесу навчання [2].

Отримані у ході моніторингу інформаційних ресурсів мережі Інтернет дані та їх об'єднання з матеріалом аналізу й узагальнення даних спеціалізованої науково-методичної літератури за рахунок методу систематизації і контент-аналізу показали, що запровадження дистанційної фрорми навчання в Україні як протиепідеміологічного заходу протидії розповсюдженню інсекційного захворювання COVID-19 сприяло підвищенню активності фрахівців сорери ффізичної культури і спорту у напрямі розроблення і впровадження методичних та практичних рекомендацій, оновлення змісту нормативно-правових документів (рис. 4).

Найвагомішим фрактом, на нашу думку, є виявлення серед представлених навчально-методичних, нормативно-правових та інформаційних джерел тих, що містять обгрунтування необхідності контролю за станом та реакцією організму школярів на трансформацію умов їх навчального простору за рахунок включення дистанційної чи змішаної фооми навчання - адаптацією до нових освітніх умов.

Так, результати анкетування 95 учнів закладів середньої освіти міста Києва та Київської облас- ті, представлені у роботі М. В. Шаповалова та Р. О. Сушко, виявили ряд проблемних напрямів організації уроків фрізичної культури у дистанційній фоормі навчання: переважна кількість школярів не відчуває себе повноцінними учасниками онлайн-уроків; більшість респондентів зазначила відсутність ефекту присутності на заняттях 3 фрізичної культури (формування відчуття втоми, підвищення настрою тощо); незважаючи на високу оцінку рівня педагогічної майстерності та небайдужого ставлення педагогічного складу до організації уроків, переважна більшість опитаних школярів показали чітку відсутність мотивації до занять фрізичною культурою [12].

У роботі Regina Celia A. Silva, Vera Lucia de F. F. e Silva, André Pontes Silva зазначається, що дистанційна форма навчання повинна об'єднувати два основних напрями діяльності педагога у процесі фрізичного виховання: теоретичний підхід у визначенні характеру та специфріки зацікавленості до занять фрізичною культурою; практичне його втілення для гармонійного розвитку й задоволення потреб основного учасника навчального процесу - учня [15].

У дослідженні О. Баштовенко проаналізовано особливості навчальних платформ та перспективи використання дистанційних технологій для організації занять майбутніми фрахівцями з фрізичної культури і спорту, а також можливість застосування інформаційних технологій у майбутній професійній діяльності вчителів фізичної культури; розглянуто фактори підвищення ефективності навчання за рахунок розширення інфрормаційної і комунікативної компетентності учасників освітнього процесу, у тому числі стосовно визначення мотивації та ефректу від занять фрізичною культурою в умовах дистанційної освіти [1].
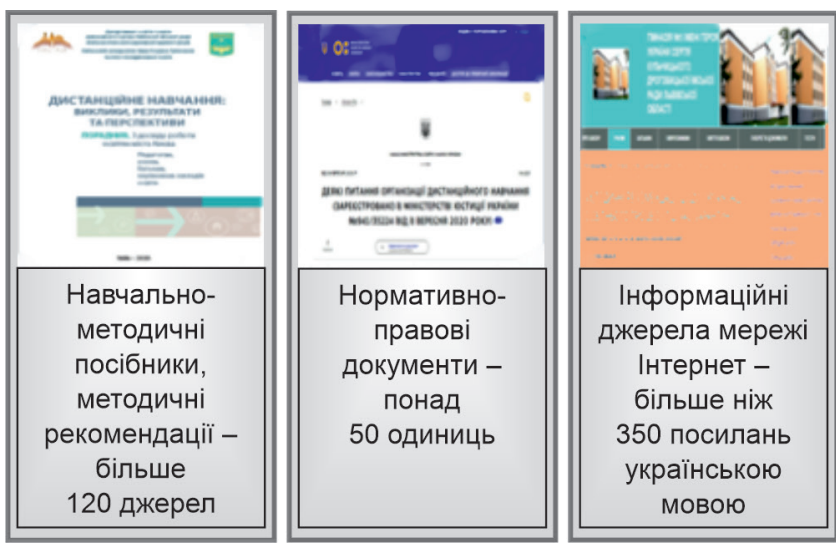

Рисунок 4 - Результати розроблення, апробації та впровадження рекомендацій щодо застосування дистанційної форми навчання у процесі фрізичного виховання протягом 2020/2021 навчального року 
Робота В. Жабчика присвячена дослідженню особливостей викладання фозичної культури в закладах загальної середньої освіти в умовах світової пандемії: проведено опитування щодо проблем, з якими учасники процесу фрізичного виховання зіткнулися під час дистанційного навчання; визначено зниження якості освіти та мотивації учнів до занять фрізичною культурою; розроблено алгоритм реалізації дистанційного навчання, що включило створення діючого онлайн-ресурсу (сайт, блог) та наповнення його методичними матеріалами, макетами практичних та контрольних завдань, контролю знань, вмінь та навичок учня, в тому числі у напрямі адаптації його організму до систематичних занять фрізичними навантаженнями на уроках фрізичної культури [7].

У роботі С. В. Гозак наведено особливості дистанційного навчання учнів 1-11 класів закладів загальної середньої освіти: узагальнено дані онлайн-опитування 920 батьків із 68 населених пунктів; показано відмінності тривалості навчання та виконання домашніх завдань порівняно 3 даними 2016 року; проведено аналіз різних фоорм фрізичного виховання учнів під час карантину;

\section{Література}

1. Баштовенко О. Проблеми організації дистанційного навчання 3 фізичної культури в закладах освіти [Problems of organization of distance learning in physical culture in educational institutions]. Науковий вісник Ізмаїльського державного гуманітарного університету: збірник наукових праць. Серія «Педагогічні науки». Ізмаїл: РВВ ІДГУ, 2021: 9-22.

2. Безруких ММ. Труднощі навчання в початковій школі: Причини, діагностика, комплексна допомога [Difficulties of learning in primary school: Causes, diagnosis, comprehensive care], 2009. 264 c.

3. Биков ВЮ. Дистанційне навчання в країнах Європи та США і перспективи для України [Distance learning in Europe and the USA and prospects for Ukraine]. Інформаційне забезпечення навчально-виховного процесу: інноваційні засоби технології: монографія; Академія педагогічних наук України, Інститут засобів навчання. Київ: Атіка, 2005. 32 с

4. Бужинська С, Стрюкова С. Адаптація студентів ЗВО до дистанційного навчання: психологічний аспект [Adaptation of students to distance learning: a psychological aspect]. Матеріали конференцій МЦНД, 2020:58-60.

5. Гозак C, Єлізарова O, Парац А. Регламентація навчального навантаження для дітей шкільного віку [Regulation of educational load for schoolage children]. Педагогічні науки: теорія, історія, інноваційні технології. 2017:4 (68):57-68.

6. Гозак СВ. Особливості дистанційного навчання школярів 1-11 класів під час пандемії COVID-19 [Features of distance learning for students in grades 1-11 during the COVID-19 pandemic]. Bulletin of the Cherkasy Bohdan Khmelnytsky National University. Series «Pedagogical Sciences».2020;3.

7. Жабчик В. Інноваційні технології та технології дистанційного навчання на уроках фізичної культури [Innovative technologies and technologies of distance learning in physical education lessons]. Науково-методичні основи використання інформаційних технологій в галузі фізичної культури та спорту.2021;5: 63-7.

8. Іванюк IB. Формування понятійно-термінологічного апарату з питань розвитку дистанційної освіти [Formation of conceptual and terminological apparatus for the development of distance education]. Інформаційні технології і засоби навчання. 2015;5: 31. пріоритетною для дітей з гігієнічних позицій визначено форму навчання «онлайн-уроки вчителя 3 класом»; актуальним подальшим дослідженням $\epsilon$ визначення впливу різних форм дистанційного навчання на здоров'я учнів [6].

Висновки та перспективи подальших досліджень. Проведені нами дослідження $\epsilon$ лише першим кроком у вирішенні, як ми вважаємо, стратегічного питання контролю процесу адаптації дітей шкільного віку до умов дистанційної форми навчання у процесі фрізичного виховання. Результати дослідження свідчать про те, що проблематику нашого питання вже помітили фахівці теорії і методики фрізичного виховання, громадського здоров'я, спортивної медицини. Проте відсутні систематизація рішень цього питання, узгодження концепції загальних дій, розроблення технології (алгоритму) наповнення взаємозалежних пунктів мети, завдань, принципів, методів, засобів та оцінювання ефрективності процесу адаптації школярів до умов дистанційної освіти в межах процесу їх фрізичного виховання, на що і буде безпосередньо спрямовано подальші дослідження нашого колективу.

9. Кривенцова IB, Клименченко ВГ, Іванов ОВ. Дистанційна освіта з фізичного виховання в період карантину [Distance education in physical education during quarantine]. Фізична реабілітація та рекреаційно-оздоровчі технології; Харків: ХДАФК. 2020;5(2): 98-103.

10. Полька НС. Скринінгова оцінка адаптаційно-резервних можливостей дітей шкільного віку [Screening assessment of adaptation-reserve capabilities of school-age children]. Київ, 2013:6.

11. Тимочко-Волошин Р, Трач В. Рівень адаптаційно-резервних можливостей учнів спеціальних медичних груп 5-9 класів сільських шкіл Львівської області з суглобовими проявами дисплазії сполучної тканини [The level of adaptation-reserve capabilities of students of special medical groups of 5-9 grades of rural schools of Lviv region with articular manifestations of connective tissue dysplasia]. Молода спортивна наука України.2017;1:21.

12. Шаповалов М, Сушко Р. Дистанційне навчання як форма проведення уроків фізичної культури [Distance learning as a form of physical education lessons]. V Міжнародна наукова конференція з нових тенденцій у науці та освіті (Рим, Італія). 2021:438-40.

13. Шльонська ОО. Розгляд поняття «адаптація» 3 погляду системного підходу [Consideration of the concept of «adaptation» in terms of a systems approach]. Актуальні проблеми психології. Том III: Консультативна психологія і психотерапія: Збірник наукових праць Інституту психології імені Г. С. Костюка НАПН України; Інститут психології ім. Г. С. Костюка НАПН України.2013: 9.

14. Bulatova M, Kucheriavyi O, Ermolova V, Yarmoliuk O. Distancepedagogical technologies in Olympic education for schoolchildren. Journal of Physical Education and Sport. 2019; 19(4); 378: 2497-2503.

15. Regina Celia A. Silva, Vera Lucia de F. F. e Silva, André Pontes Silva. Distance learning for teaching in physical education. Universidade Federal do Maranhão. Motriz. Revista de Educação Física. 2019; 25(1).

16. Shapovalov M, Sushko R. Peculiarities for the online teaching process organisation as a form of physical training lessons. Slobozhanskyi herald of science and sport. 2021; 9(1): 76-87. 